\title{
Oxidative Removal of Cu from Carbon-saturated Iron via Ag Phase into $\mathrm{B}_{2} \mathrm{O}_{3}$ Flux
}

\author{
Katsuhiro YAMAGUCHI and Hideki ONO
}

Division of Materials and Manufacturing Science, Graduate School of Engineering, Osaka University, 2-1 Yamadaoka, Suita, Osaka, 565-0871 Japan.

(Received on August 18, 2011; accepted on October 6, 2011)

\begin{abstract}
The oxidative removal of $\mathrm{Cu}$ from carbon-saturated iron via the $\mathrm{Ag}$ phase into $\mathrm{B}_{2} \mathrm{O}_{3}$ flux was attempted at $1523 \mathrm{~K}$. The $\mathrm{Cu}$ content was reduced from 4 to below 0.2 mass \%, and $\mathrm{Cu}$ in the molten iron could be removed into the $\mathrm{B}_{2} \mathrm{O}_{3}$ flux by the method proposed in this study. Furthermore, the $\mathrm{Cu}$ distribution ratio between the $\mathrm{B}_{2} \mathrm{O}_{3}$ flux and $\mathrm{Ag}, \mathrm{L}_{\mathrm{Cu} \text { (flux-Ag) }}\left(=[\text { mass } \% \mathrm{Cu}]_{(\text {in flux }} /[\text { mass } \% \mathrm{Cu}]_{(\text {in Ag) }}\right)$ and the activity coefficients of

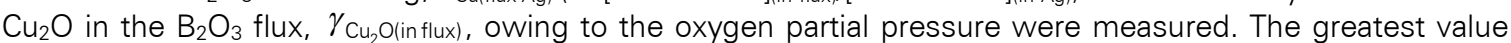
of $L_{\mathrm{Cu}(f \mathrm{flu}-\mathrm{Ag})}$ was found to be 17 at $0.6 \mathrm{~atm}$ of oxygen partial pressure. Using this value, the distribution ratio of $\mathrm{Cu}$ between the $\mathrm{B}_{2} \mathrm{O}_{3}$ flux and carbon-saturated iron is calculated to be 120 at $1523 \mathrm{~K}$. To predict the behavior of solute elements in the Ag phase, a numerical calculation of mass transfer based on Fick's second law is performed and the optimum execution method of oxidative removal of $\mathrm{Cu}$ is discussed.
\end{abstract}

KEY WORDS: tramp element; copper; silver; boron oxide; iron scrap; oxidation; recycle.

\section{Introduction}

In Japan, approximately 30 million tons of waste steel scrap is purchased each year and it is estimated that approximately 3 million tons thereof is exported. ${ }^{1)}$ Almost all of the iron ore and coal used in Japan is imported and so, waste scrap is a valuable iron source and should be recycled as far as possible. Furthermore, recycling the thermochemicallyreduced steel scrap reduces carbon dioxide emissions. However, waste steel scrap contains large amounts of $\mathrm{Cu}$ and $\mathrm{Sn}$, which are deleterious elements in steel-making and cannot be removed by oxidizing-refining in a conventional steelmaking process. Therefore, these elements accumulate in the molten iron and become a major problem in recycling steel scrap with $\mathrm{Cu}$ being the most troublesome element. The amount of available waste steel scrap with low $\mathrm{Cu}$ content is declining and such scrap is difficult to recycle without diluting the $\mathrm{Cu}$ content with pig iron. Therefore, the establishment of an industrial method for removing $\mathrm{Cu}$ from iron is on urgent necessity.

$\mathrm{Cu}$ attached to steel can be removed by advanced magnetic separation after shredding or $\mathrm{Cu}$ dissolution into a solvent such as molten $\mathrm{Al}^{2-4)}$ or aqueous $\mathrm{NH}_{3}$ solution. ${ }^{5)}$ However, complete separation of the $\mathrm{Cu}$ from the steel is difficult in reality and the dissolution of some of the $\mathrm{Cu}$ into the molten iron is unavoidable.

The liquid phase of the $\mathrm{Fe}-\mathrm{Cu}$ binary system is miscible over the whole composition range. It has been reported that the liquid separates into $\mathrm{Fe}$ - and $\mathrm{Cu}$-rich phases by adding $\mathrm{C}^{6,7)}$ and $\mathrm{B} .{ }^{8)}$ However, the $\mathrm{Cu}$ content of the Fe-rich phase is approximately 5 mass $\%$ and it is difficult to use this Ferich phase as an iron source. On the other hand, using the immiscibility of $\mathrm{Ag}$ and $\mathrm{Pb}$ in $\mathrm{Fe}$, the distribution of $\mathrm{Cu}$ between the $\mathrm{Fe}$ and $\mathrm{Ag}(\mathrm{Pb})$ phases and reduction of the $\mathrm{Cu}$ content of the $\mathrm{Fe}$ phase has been achieved. ${ }^{7)}$ However, because the distribution ratio of $\mathrm{Cu}$ between $\mathrm{Ag}(\mathrm{Pb})$ and $\mathrm{Fe}$ is insufficient, the quantity of $\mathrm{Ag}(\mathrm{Pb})$ necessary for this removal treatment is large and this method is not economically viable. We have attempted the oxidative removal of $\mathrm{Cu}^{9)}$ and $\mathrm{Sn}^{10)}$ from $\mathrm{Fe}-\mathrm{C}$ (satd.) via $\mathrm{Ag}$, and the $\mathrm{Cu}$ and $\mathrm{Sn}$ contents of the $\mathrm{Fe}-\mathrm{C}$ (satd.) have been decreased to 0.4 mass $\%$ and below 0.001 mass $\%$, respectively. The lower limit of $\mathrm{Cu}$ in the $\mathrm{Fe}-\mathrm{C}$ (satd.) can be decreased by dissolving $\mathrm{Cu}$ oxide into the oxide flux and decreasing the $\mathrm{Cu}$ oxide activity. Therefore, designing the oxide flux with a strong affinity for the $\mathrm{Cu}$ oxide is important. In this work, the activity coefficient of $\mathrm{Cu}_{2} \mathrm{O}$ in the $\mathrm{B}_{2} \mathrm{O}_{3}$ flux is measured. In addition, the oxidative removal of $\mathrm{Cu}$ from the $\mathrm{Fe}-\mathrm{C}$ (satd.) via the Ag phase into the $\mathrm{B}_{2} \mathrm{O}_{3}$ flux is performed at $1523 \mathrm{~K}$.

\section{Principle}

2.1. Oxidative Removal of $\mathrm{Cu}$ from Molten Iron via $\mathrm{Ag}$ Oxidative refining does not apply to the removal of $\mathrm{Cu}$ because the Gibbs free energy of forming $\mathrm{Cu}$ oxide is higher than that of Fe. In this work, $\mathrm{Ag}$ is used as a solvent for $\mathrm{Cu}$ because $\mathrm{Ag}$ and $\mathrm{Fe}$ are immiscible and $\mathrm{Cu}$ is more easily oxidized than Ag. A schematic diagram of the oxidative removal of $\mathrm{Cu}$ from iron is shown in Fig. 1. The distribution of $\mathrm{Cu}$ between $\mathrm{Fe}-\mathrm{C}$ (satd.) and $\mathrm{Ag}$ is expressed as shown in Eq. (1):

$$
\underline{\mathrm{Cu}}_{(\mathrm{inFe}-\mathrm{C})}=\underline{\mathrm{Cu}}_{(\mathrm{in} \mathrm{Ag})}
$$

The oxidation reaction of $\mathrm{Cu}$ in the $\mathrm{Ag}$ is expressed as 


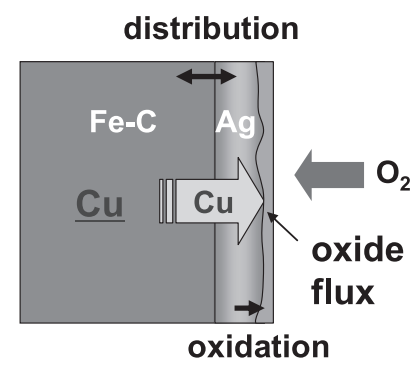

Fig. 1. Oxidative removal of $\mathrm{Cu}$ into oxide flux via $\mathrm{Ag}$ phase.

shown in Eq. (2):

$$
\underline{\mathrm{Cu}}_{(\mathrm{in} \mathrm{Ag})}+\frac{1}{4} \mathrm{O}_{2}(\mathrm{~g})=\frac{1}{2} \mathrm{Cu}_{2} \mathrm{O}(\mathrm{l})
$$

By combining Eqs. (1) and (2), Eq. (3) is obtained and the oxidative removal of $\mathrm{Cu}$ from molten iron is possible without oxidation of the $\mathrm{Fe}-\mathrm{C}$ (satd.). The $\mathrm{Cu}$ content of the $\mathrm{Fe}-$ $\mathrm{C}$ (satd.) is calculated from the equilibrium relation of Eq. (3) and is shown in Eq. (4)

$$
\begin{gathered}
\underline{\mathrm{Cu}}_{(\mathrm{in} \mathrm{Fe}-\mathrm{C})}+\frac{1}{4} \mathrm{O}_{2}(\mathrm{~g})=\frac{1}{2} \mathrm{Cu}_{2} \mathrm{O}(\mathrm{l}) \\
N_{\mathrm{Cu}(\mathrm{in} \mathrm{Fe}-\mathrm{C})}=\frac{a_{\mathrm{Cu}_{2} \mathrm{O}}^{1 / 2}}{\gamma_{\mathrm{Cu}(\mathrm{in} \mathrm{Fe}-\mathrm{C})}^{\circ} K_{(3)} p_{\mathrm{O}_{2}}^{1 / 4}} . . .
\end{gathered}
$$

where $N_{i(\text { in } j)}, K_{(3)}, \gamma_{i(\text { in } j)}^{\circ}, p_{\mathrm{O}_{2}}$ and $a_{i}$ are the mole fraction of $i$ in $j$, the equilibrium constant of Eq. (3) $(=102.3),{ }^{11)}$ the activity coefficient of $i$ in $j$ at infinite dilution in the pure substance reference, the partial pressure of oxygen and the activity of $i$ in the pure substance reference, respectively. By substituting for $\gamma_{\mathrm{Cu}(\mathrm{in} \mathrm{Fe}-\mathrm{C})}^{\circ}(=50.2),{ }^{9)} p_{\mathrm{O}_{2}}(=1$ atm $)$ and $a_{\mathrm{Cu}_{2} \mathrm{O}}$ $(=1), N_{\mathrm{Cu}(\mathrm{in} \text { Fe-C) }}$ is calculated to be $1.96 \times 10^{-3}(0.26 \operatorname{mass} \%)$ and this value is the lower limit of $\mathrm{Cu}$. In Eq. (4), the $\mathrm{Cu}$ content of the $\mathrm{Fe}-\mathrm{C}$ (satd.) can be decreased by decreasing $a_{\mathrm{Cu}_{2} \mathrm{O}}$. Besides, the oxide flux, which is melted at the operating temperature and has a strong affinity for $\mathrm{Cu}_{2} \mathrm{O}$, should be selected for decreasing $a_{\mathrm{Cu}_{2} \mathrm{O}}$ effectively.

Morinaga et al. ${ }^{12)}$ regarded the basicity of slag as the quantity which was proportional to the reciprocal of the coulomb force between cation and oxide ion and proposed the basicity parameter, $B$, as shown in Eq. (5)

$$
\begin{aligned}
& B_{i}^{\prime}=\left[\frac{z_{i} \times 2}{\left(r_{i}+1.40\right)^{2}}\right]^{-1} \\
& B_{i}=\frac{B_{i}^{\prime}-B_{\mathrm{SiO}_{2}}^{\prime}}{B_{\mathrm{CaO}}^{\prime}-B_{\mathrm{SiO}_{2}}^{\prime}} \\
& B=\sum_{i} n_{i} B_{i}
\end{aligned}
$$

where $z_{i}, r_{i}$ and $n_{i}$ are electrical charge, ion radius $(\AA)$ and ratio of composition of cation $i$, respectively. Values of the basicity parameter, $B$, of representative oxides based on Eq. (5) are shown in Table 1. In Table 1, oxides with large basicity parameter $B$ are strongly basic. Because $\mathrm{Cu}_{2} \mathrm{O}$ is classified as a basic oxide as shown in Table 1, oxides such as $\mathrm{B}_{2} \mathrm{O}_{3}$ and $\mathrm{SiO}_{2}$ which are classified as acidic oxides seem to have a large $\mathrm{Cu}$ capacity.
Table 1. Values of the basicity parameter, $B$, of representative oxides.

\begin{tabular}{cc}
\hline $\mathrm{Oxide}_{2}$ & $\mathrm{~B}$ \\
\hline $\mathrm{K}_{2} \mathrm{O}$ & 3.381 \\
$\mathrm{Na}_{2} \mathrm{O}$ & 2.349 \\
$\mathrm{Cu}_{2} \mathrm{O}$ & 2.326 \\
$\mathrm{Li}_{2} \mathrm{O}$ & 1.719 \\
$\mathrm{BaO}$ & 1.561 \\
$\mathrm{PbO}$ & 1.307 \\
$\mathrm{SrO}$ & 1.269 \\
$\mathrm{CaO}$ & 1.000 \\
$\mathrm{SnO}$ & 0.931 \\
$\mathrm{FeO}$ & 0.723 \\
$\mathrm{ZnO}$ & 0.723 \\
$\mathrm{CuO}$ & 0.703 \\
$\mathrm{MgO}$ & 0.641 \\
$\mathrm{Bi}_{2} \mathrm{O}_{3}$ & 0.512 \\
$\mathrm{Fe}_{2} \mathrm{O}_{3}$ & 0.282 \\
$\mathrm{Ga}_{2} \mathrm{O}_{3}$ & 0.269 \\
$\mathrm{Al}_{2} \mathrm{O}_{3}$ & 0.198 \\
$\mathrm{ZrO}_{2}$ & 0.190 \\
$\mathrm{SnO}_{2}$ & 0.148 \\
$\mathrm{TiO}_{2}$ & 0.133 \\
$\mathrm{TeO}_{2}$ & 0.078 \\
$\mathrm{GeO}_{2}$ & 0.045 \\
$\mathrm{~B}_{2} \mathrm{O}_{3}$ & 0.026 \\
$\mathrm{SiO}_{2}$ & 0.000 \\
$\mathrm{P}_{2} \mathrm{O}_{5}$ & \\
& -103 \\
\hline & \\
\hline & \\
\hline
\end{tabular}

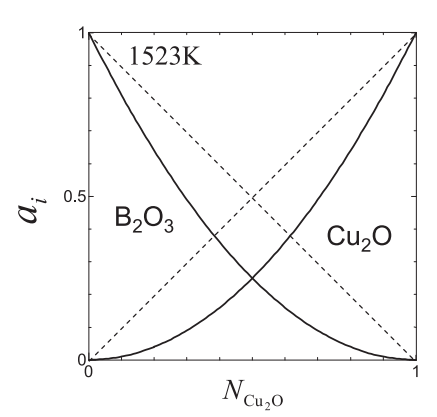

Fig. 2. Activity curve of $\mathrm{Cu}_{2} \mathrm{O}-\mathrm{B}_{2} \mathrm{O}_{3}$ system calculated by FactSage 6.1 at $1523 \mathrm{~K}$

The melting point of $\mathrm{B}_{2} \mathrm{O}_{3}$ is $753 \mathrm{~K}$ and the $\mathrm{B}_{2} \mathrm{O}_{3}$ is liquid at the experimental temperatures of this work at $1523 \mathrm{~K}$. The activity curve of the $\mathrm{B}_{2} \mathrm{O}_{3}-\mathrm{Cu}_{2} \mathrm{O}$ system calculated using FactSage 6.1 at $1523 \mathrm{~K}$ is shown in Fig. 2. The $\mathrm{B}_{2} \mathrm{O}_{3}-$ $\mathrm{Cu}_{2} \mathrm{O}$ system has a negative bias and the $\mathrm{B}_{2} \mathrm{O}_{3}$ is expected to have a large $\mathrm{Cu}$ capacity.

In this work, the activity coefficient of $\mathrm{Cu}_{2} \mathrm{O}$ in the $\mathrm{B}_{2} \mathrm{O}_{3}$ flux, $\gamma_{\mathrm{Cu}_{2} \mathrm{O}(\text { in flux) }}$, is measured to determine the $\mathrm{Cu}$ capacity. Besides, the oxidative removal of $\mathrm{Cu}$ from the $\mathrm{Fe}-\mathrm{C}$ (satd.) via $\mathrm{Ag}$ into the $\mathrm{B}_{2} \mathrm{O}_{3}$ flux is attempted. The necessary quantity of $\mathrm{Ag}$ is low in principle because $\mathrm{Ag}$ is used for the distribution of $\mathrm{Cu}$ between the $\mathrm{Fe}-\mathrm{C}$ (satd.) and $\mathrm{Ag}$ and as a 
solvent for the oxidative removal of $\mathrm{Cu}$.

Carbon plays an important role in lowering the melting point of iron and raising the distribution ratio of $\mathrm{Cu}$ between the Fe and Ag.

\section{Experimental}

The experimental apparatus consisted of a mullite tube (70 $\mathrm{mm}$ outer diameter, $60 \mathrm{~mm}$ inner diameter, $1000 \mathrm{~mm}$ length) and vertical $\mathrm{MoSi}_{2}$ electric resistance furnace connected to a proportional integral derivative action controller with a $\mathrm{Pt}-6 \% \mathrm{Rh} / \mathrm{Pt}-30 \% \mathrm{Rh}$ thermocouple.

\subsection{Measurement of the Activity Coefficient of $\mathrm{Cu}_{2} \mathrm{O}$ in the $\mathrm{B}_{2} \mathrm{O}_{3}$ Flux}

The experimental conditions are shown in Table 2. Ten grams of reagent grade Ag (purity: 99.9\%), 0.20-0.22 $\mathrm{g}$ of reagent grade $\mathrm{Cu}$ (purity: 99\%) and reagent grade $\mathrm{B}_{2} \mathrm{O}_{3}$ (purity: 99.9\%) were charged in an alumina crucible $(38 \mathrm{~mm}$ outer diameter, $45 \mathrm{~mm}$ height, $30 \mathrm{~cm}^{3}$ capacity). The crucible was inserted into an alumina holder ( $52 \mathrm{~mm}$ outer diameter, $42 \mathrm{~mm}$ inner diameter, $100 \mathrm{~mm}$ height) and the samples were melted in a furnace under argon atmosphere at $1523 \mathrm{~K}$. After the sample had melted, the mixed oxygen and argon gas (total flow: $150 \mathrm{~cm}^{3} / \mathrm{min}$ (STP), $p_{\mathrm{O}_{2}}: 0.1-1 \mathrm{~atm}$ ) was blown onto the $\mathrm{Ag}-\mathrm{Cu}$ alloy from $20 \mathrm{~mm}$ above the sample for over $1-12 \mathrm{~h}$ to attain equilibrium. The alumina holder was withdrawn from the furnace, and the sample was quenched rapidly under argon gas flow. The $\mathrm{Cu}$ content of the $\mathrm{Ag}$ and the $\mathrm{Ag}, \mathrm{Cu}, \mathrm{Al}$ and $\mathrm{B}$ contents of the flux were analyzed by inductively coupled plasma-atomic emission spectrometry (ICP-AES).

\subsection{Oxidative Removal of $\mathrm{Cu}$ from Carbon-saturated Iron via Ag Phase into $\mathrm{B}_{2} \mathrm{O}_{3}$ Flux}

The alumina crucibles and tubes shown in Figs. 3(a) (Run 9), 3(b) (Runs 10-17) were used in the experiment with experimental conditions shown in Table 3. Runs 9-11 were performed without $\mathrm{B}_{2} \mathrm{O}_{3}$. The $\mathrm{B}_{2} \mathrm{O}_{3}$ and $\mathrm{B}_{2} \mathrm{O}_{3}-\mathrm{Al}_{2} \mathrm{O}_{3}-\mathrm{Ag}_{2} \mathrm{O}$ fluxes used for the experiments were made in advance in the following manner and the compositions of these fluxes were analyzed by ICP-AES:

(1) $\mathrm{B}_{2} \mathrm{O}_{3}$ flux: the reagent $\mathrm{B}_{2} \mathrm{O}_{3}$ contained in an alumina crucible $\left(38 \mathrm{~mm}\right.$ outer diameter, $45 \mathrm{~mm}$ height, $30 \mathrm{~cm}^{3}$ capacity) was inserted into the furnace at $1523 \mathrm{~K}$ under an

Table 2. Experimental conditions for the measurement of the activity coefficient of $\mathrm{Cu}_{2} \mathrm{O}$

\begin{tabular}{cccccc}
\hline \multirow{2}{*}{ No. } & \multicolumn{4}{c}{ Initial mass of reagent $(\mathrm{g})$} & \\
\cline { 2 - 4 } & $\mathrm{Ag}$ & $\mathrm{Cu}$ & $\mathrm{B}_{2} \mathrm{O}_{3}$ & & \\
\hline 1 & 10 & 0.20 & 0.45 & 6 & 0.1 \\
2 & 10 & 0.20 & 0.50 & 6 & 0.4 \\
3 & 10 & 0.20 & 0.50 & 6 & 0.6 \\
4 & 10 & 0.21 & 0.46 & 6 & 0.6 \\
5 & 10 & 0.21 & 0.51 & 1 & 1 \\
6 & 10 & 0.20 & 0.46 & 6 & 1 \\
7 & 10 & 0.22 & 0.50 & 12 & 1 \\
8 & 10 & 0.22 & 0.97 & 12 & 1 \\
\hline
\end{tabular}

argon atmosphere for $3 \mathrm{~h}$. The $\mathrm{Al}_{2} \mathrm{O}_{3}$ content of the flux was 0.4 mass $\%$ and this value is lower than the solubility from the phase diagram of the $\mathrm{B}_{2} \mathrm{O}_{3}-\mathrm{Al}_{2} \mathrm{O}_{3}$ system (approximately 4 mass $\%){ }^{13)}$

(2) $\mathrm{B}_{2} \mathrm{O}_{3}-\mathrm{Al}_{2} \mathrm{O}_{3}-\mathrm{Ag}_{2} \mathrm{O}$ flux: the reagent $\mathrm{B}_{2} \mathrm{O}_{3}$ and sufficient mass of $\mathrm{Ag}$ reagent were contained in the alumina crucible $\left(38 \mathrm{~mm}\right.$ outer diameter, $45 \mathrm{~mm}$ height, $30 \mathrm{~cm}^{3}$ capacity) and inserted into the furnace at $1523 \mathrm{~K}$ under an argon atmosphere and the $\mathrm{B}_{2} \mathrm{O}_{3}$ and $\mathrm{Ag}$ were pre-melted. An alumina tube ( $3 \mathrm{~mm}$ outer diameter, $2 \mathrm{~mm}$ inner diameter) was inserted in the melt and oxygen gas $\left(150 \mathrm{~cm}^{3} / \mathrm{min}\right.$ (STP)) was blown into the melts for $1.5 \mathrm{~h}$. The $\mathrm{B}_{2} \mathrm{O}_{3}-6-7$ mass $\% \mathrm{Al}_{2} \mathrm{O}_{3}-15$ mass $\% \mathrm{Ag}_{2} \mathrm{O}$ was obtained.

A small path was made at the lowest point of the alumina tube $(21 \mathrm{~mm}$ outer diameter, $16 \mathrm{~mm}$ inner diameter, $50 \mathrm{~mm}$ length), and the tube was set in the alumina crucible as shown in Figs. 3(a) and 3(b). The reagents $\mathrm{Ag}$ and $\mathrm{Cu}$ were weighed and placed in and outside the alumina tube. A graphite tube was inserted into the alumina tube, and the prepared $\mathrm{Fe}-4$ mass $\% \mathrm{Cu}-\mathrm{C}$ (satd.) alloy was placed in the graphite tube. A graphite lid was placed on the graphite tube and the alumina tube was sealed with an alumina lid and cement. The alumina crucible was placed in an alumina holder (52 $\mathrm{mm}$ outer diameter, $42 \mathrm{~mm}$ inner diameter, $100 \mathrm{~mm}$ height) and inserted into the furnace under an argon atmosphere $\left(100 \mathrm{~cm}^{3} / \mathrm{min}(\mathrm{STP})\right)$ at room temperature. The furnace was heated to $1523 \mathrm{~K}$ for $2.5 \mathrm{~h}$. For Run 11 shown in Fig. 3(b), oxygen gas $\left(15 \mathrm{~cm}^{3} / \mathrm{min}\right.$ (STP)) was blown into the Ag from the alumina tube $(3 \mathrm{~mm}$ outer diameter, $2 \mathrm{~mm}$ inner diameter) for $0.5 \mathrm{~h}$. For Runs 12-17, oxygen gas $\left(150 \mathrm{~cm}^{3} / \mathrm{min}\right.$ (STP)) was blown onto the Ag from the alumina tube which was set approximately $40 \mathrm{~mm}$ above the metal surface, as shown in Fig. 3(b). For Runs 9-13, the samples were pre-melted at $1373 \mathrm{~K}$ under an argon atmo-

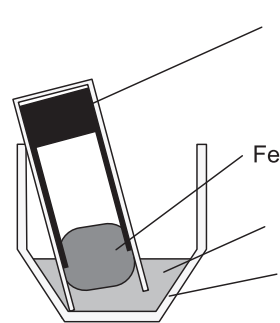

(a)

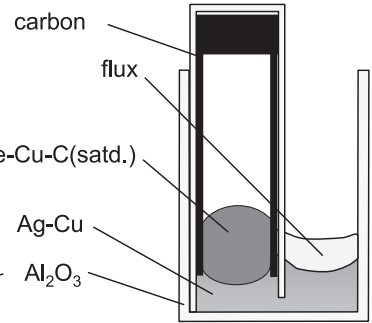

(b)
Fig. 3. Schematic cross section of the crucible.

Table 3. Experimental conditions of oxidative removal of $\mathrm{Cu}$ into $\mathrm{B}_{2} \mathrm{O}_{3}$ flux via $\mathrm{Ag}$.

\begin{tabular}{cccccccccc}
\hline No. & Flux & $\begin{array}{c}\mathrm{Ag} \\
(\mathrm{g})\end{array}$ & $\begin{array}{c}\mathrm{Cu} \\
(\mathrm{g})\end{array}$ & $\begin{array}{c}\mathrm{Fe} \text { alloy } \\
(\mathrm{g})\end{array}$ & $\begin{array}{c}{[\mathrm{mass} \% \mathrm{Cu}]} \\
(\mathrm{in} \mathrm{Fe})\end{array}$ & $\begin{array}{c}\mathrm{Flux} \\
(\mathrm{g})\end{array}$ & $\begin{array}{c}p_{\mathrm{O}_{2}} \\
(\mathrm{~atm})\end{array}$ & $\begin{array}{c}\text { Time } \\
(\mathrm{h})\end{array}$ & $\begin{array}{c}\text { Flow rate } \\
\left(\mathrm{cm}^{3} / \mathrm{min}\right)\end{array}$ \\
\hline 9 & & 30 & 0.61 & 9.9 & 3.0 & & & 7 & 15 \\
10 & - & 65 & 2.0 & 7.4 & 3.0 & - & 1 & 0.25 & 100 \\
11 & & 65 & 2.0 & 7.7 & 3.9 & & & 0.5 & 15 \\
\hline 12 & & 60 & 0.55 & 8.0 & 3.9 & 3.5 & 3 & 150 \\
13 & $\mathrm{~B}_{2} \mathrm{O}_{3}-\mathrm{Al}_{2} \mathrm{O}_{3}$ & 60 & 0.17 & 8.0 & 3.9 & 3.6 & 3 & \\
\hline 14 & & 59 & 0.55 & 7.9 & 3.9 & 6.0 & 1 & \\
15 & $\mathrm{~B}_{2} \mathrm{O}_{3}-$ & 60 & 1.0 & 7.9 & 3.9 & 3.5 & 3 & 150 \\
16 & $\mathrm{Al}_{2} \mathrm{O}_{3}-$ & 59 & 0.56 & 7.9 & 3.9 & 6.0 & 1 & 1 & \\
17 & $\mathrm{Ag}_{2} \mathrm{O}$ & 59 & 60 & 1.0 & 7.8 & 3.9 & 3.7 & 3.5 & \\
\hline
\end{tabular}


Table 4. Experimental results from the measurement of the activity coefficient of $\mathrm{Cu}_{2} \mathrm{O}$.

\begin{tabular}{|c|c|c|c|c|c|c|c|c|c|c|c|}
\hline \multirow{2}{*}{ No. } & \multirow{2}{*}{$\frac{\operatorname{In~} \mathrm{Ag}(\operatorname{mass} \%)}{\mathrm{Cu}}$} & \multicolumn{4}{|c|}{ In oxide flux (mass\%) } & \multirow{2}{*}{$L_{\mathrm{Cu}(\text { flux-Ag) }}$} & \multicolumn{4}{|c|}{ Flux composition (mole fraction) } & \multirow{2}{*}{$\gamma_{\mathrm{Cu}_{2} \mathrm{O}}$} \\
\hline & & $\mathrm{Cu}$ & $\mathrm{Ag}$ & $\mathrm{Al}$ & $\mathrm{B}$ & & $N_{\mathrm{Cu}_{2} \mathrm{O}}$ & $N_{\mathrm{Ag}_{2} \mathrm{O}}$ & $N_{\mathrm{Al}_{2} \mathrm{O}_{3}}$ & $N_{\mathrm{B}_{2} \mathrm{O}_{3}}$ & \\
\hline 1 & 0.779 & 7.1 & 26.6 & 8.5 & 7.22 & 9.1 & 0.084 & 0.184 & 0.234 & 0.498 & 0.676 \\
\hline 2 & 0.543 & 7.3 & 35.4 & 9.9 & 7.66 & 13.4 & 0.076 & 0.216 & 0.242 & 0.467 & 0.729 \\
\hline 3 & 0.475 & 8.0 & 38.1 & 10.1 & 7.45 & 16.8 & 0.082 & 0.229 & 0.242 & 0.447 & 0.634 \\
\hline 4 & 0.492 & 7.6 & 39.3 & 9.9 & 7.53 & 15.4 & 0.077 & 0.236 & 0.236 & 0.451 & 0.719 \\
\hline 5 & 0.499 & 7.5 & 39.0 & 9.3 & 7.19 & 15.1 & 0.079 & 0.242 & 0.232 & 0.447 & 0.927 \\
\hline 6 & 0.537 & 8.0 & 40.5 & 10.5 & 4.08 & 14.8 & 0.099 & 0.297 & 0.306 & 0.298 & 0.861 \\
\hline 7 & 0.638 & 8.3 & 38.6 & 10.8 & 3.63 & 13.0 & 0.106 & 0.292 & 0.327 & 0.275 & 1.128 \\
\hline 8 & 0.352 & 5.1 & 41.7 & 10.8 & 4.79 & 14.6 & 0.062 & 0.295 & 0.306 & 0.338 & 0.595 \\
\hline
\end{tabular}

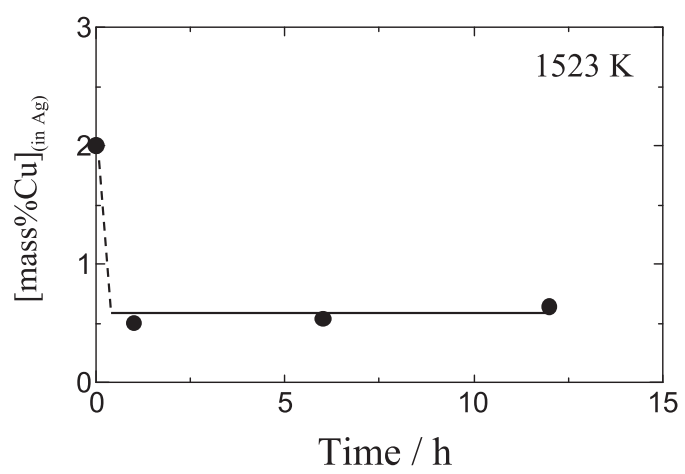

Fig. 4. Determination of equilibration time.

sphere $\left(100 \mathrm{~cm}^{3} / \mathrm{min}(\mathrm{STP})\right)$ for $0.5 \mathrm{~h}$ to melt the $\mathrm{Ag}-\mathrm{Cu}$ alloy and the furnace was heated to $1523 \mathrm{~K}$ and held for $0.5 \mathrm{~h}$ to distribute $\mathrm{Cu}$ between the $\mathrm{Fe}-\mathrm{C}$ (satd.) and $\mathrm{Ag}$. Thereafter, oxygen gas was blown onto the flux.

The alumina holder was withdrawn from the furnace, and the sample was quenched rapidly under argon. The $\mathrm{Cu}$ content of the $\mathrm{Ag}$, the $\mathrm{Cu}$ and $\mathrm{Ag}$ contents of the $\mathrm{Fe}-\mathrm{C}$ (satd.) and the $\mathrm{Cu}, \mathrm{Ag}, \mathrm{Al}$ and $\mathrm{B}$ contents of the flux were analyzed by ICP-AES. The powder X-ray diffraction spectrum of the oxides which were formed at the path in Run 9 was performed. Analysis of the Ag both inside and outside the alumina tube was performed separately. In this work, the $\mathrm{C}$ content of the $\mathrm{Fe}-\mathrm{C}$ (satd.) was approximately 4.5 mass\%. $\left.{ }^{9}\right)$

\section{Results}

\subsection{Measurement of the Activity Coefficient of $\mathrm{Cu}_{2} \mathrm{O}$ in the $\mathrm{B}_{2} \mathrm{O}_{3}$ Flux}

The experimental results are shown in Table 4. The mole fraction of each oxide is calculated assuming the component oxides are $\mathrm{B}_{2} \mathrm{O}_{3}, \mathrm{Cu}_{2} \mathrm{O}, \mathrm{Al}_{2} \mathrm{O}_{3}$ and $\mathrm{Ag}_{2} \mathrm{O}$. The distribution ratio of $\mathrm{Cu}$ between the $i$ and $j$ phases is defined by $L_{\mathrm{Cu}(i-j)}$ $\left(=[\text { mass } \% \mathrm{Cu}]_{(\text {in } i)} /[\text { mass } \% \mathrm{Cu}]_{(\text {in } j)}\right)$. In previous work, the $\mathrm{Cu}$ content of the $\mathrm{Ag}$ was measured to be approximately 1.5 mass $\%$, measured without oxide flux in an oxygen atmosphere (1 atm) at $1523 \mathrm{~K} .{ }^{9)}$ In contrast with previous work, the $\mathrm{Cu}$ content of the $\mathrm{Ag}$ of this work (Runs 1-8) is measured to be below 1.5 mass $\%$ which shows that the $\mathrm{B}_{2} \mathrm{O}_{3}$ flux has an absorption capacity for $\mathrm{Cu}_{2} \mathrm{O}$. The relationship between the holding time and $\mathrm{Cu}$ content of the $\mathrm{Ag}$ is shown in Fig. 4 for the experiments performed in oxygen atmosphere $(1 \mathrm{~atm})$ and for the same initial mass ratio between

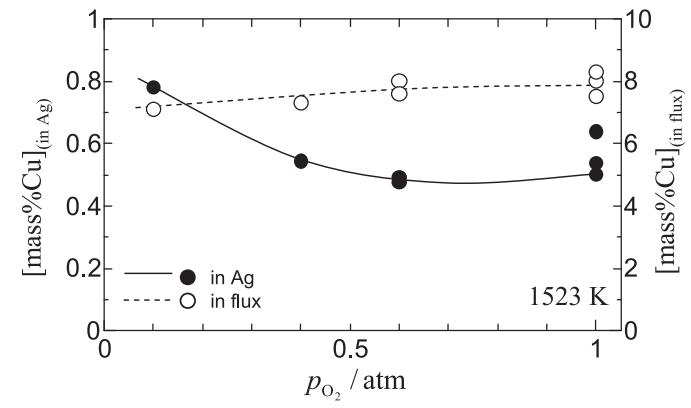

Fig. 5. Relationship between oxygen partial pressure and $\mathrm{Cu}$ content of $\mathrm{Ag}$ and flux.

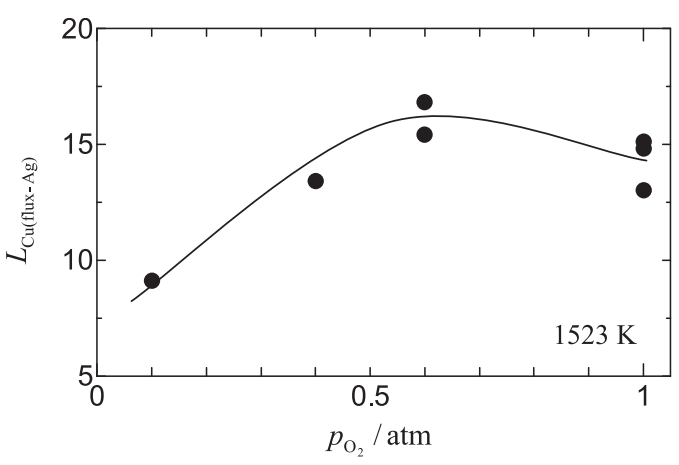

Fig. 6. Change of distribution ratio owing to oxygen partial pressure.

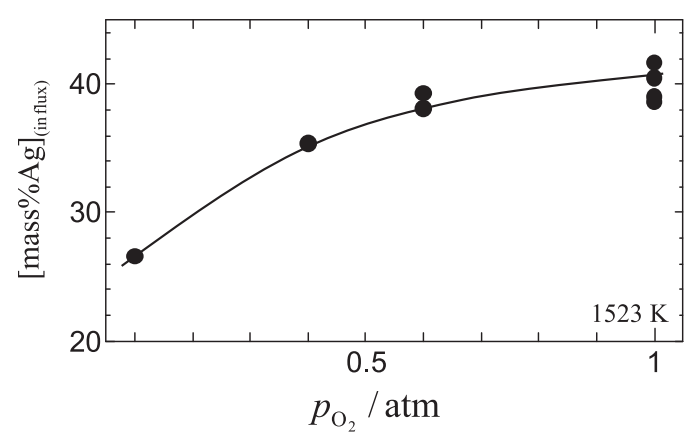

Fig. 7. Oxidation of $\mathrm{Ag}$ into the $\mathrm{B}_{2} \mathrm{O}_{3}$ flux.

$\mathrm{B}_{2} \mathrm{O}_{3}$ and $\mathrm{Cu}$ (approximately 2). As shown in Fig. 4, the $\mathrm{Cu}$ content of the $\mathrm{Ag}$ reaches a constant value after approximately $1 \mathrm{~h}$. Therefore, the equilibration time is determined to be less than $1 \mathrm{~h}$ and the other experiments were performed for longer than $6 \mathrm{~h}$ to give sufficient time for equil- 
ISIJ International, Vol. 52 (2012), No. 1

Table 5. Experimental results of the oxidative removal of $\mathrm{Cu}$ into $\mathrm{B}_{2} \mathrm{O}_{3}$ flux via $\mathrm{Ag}$.

\begin{tabular}{|c|c|c|c|c|c|c|c|c|c|c|c|c|c|}
\hline \multirow{3}{*}{ No. } & \multicolumn{2}{|c|}{$\begin{array}{l}\text { Before oxidation } \\
\text { (calc.) (mass } \%)\end{array}$} & \multicolumn{9}{|c|}{ Experimental result (mass\%) } & \multirow{2}{*}{\multicolumn{2}{|c|}{$L_{\mathrm{Cu}(\mathrm{Ag}-\mathrm{Fe})}$}} \\
\hline & In $\mathrm{Ag}$ & In Fe & \multicolumn{2}{|c|}{ In $\mathrm{Ag}$} & \multicolumn{2}{|c|}{ In Fe } & \multicolumn{5}{|c|}{ In $\mathrm{B}_{2} \mathrm{O}_{3}$} & & \\
\hline & & & $\mathrm{Cu}$ (outer) & $\mathrm{Cu}$ (innner) & $\mathrm{Cu}$ & $\mathrm{Ag}$ & $\mathrm{Cu}$ & $\mathrm{Ag}$ & $\mathrm{B}$ & $\mathrm{Fe}$ & $\mathrm{Al}$ & (outer) & (inner) \\
\hline 9 & 2.92 & 0.41 & 2.75 & 1.61 & 0.38 & 0.08 & & & & & & 4.2 & 7.2 \\
\hline 10 & 3.27 & 0.46 & - & - & - & - & & & - & & & - & - \\
\hline 11 & 3.53 & 0.49 & 3.22 & 3.12 & 0.47 & 0.06 & & & & & & 6.6 & 6.9 \\
\hline 12 & 1.40 & 0.20 & 1.47 & 1.37 & 0.18 & 0.06 & 0.068 & 0.193 & 30.6 & 0.51 & 1.46 & 8.3 & 7.0 \\
\hline 13 & 0.79 & 0.11 & 0.81 & 0.78 & 0.11 & 0.07 & 0.044 & 0.151 & 32.1 & 0.49 & 1.46 & 7.3 & 7.1 \\
\hline 14 & 1.48 & 0.21 & 1.25 & 1.36 & 0.19 & 0.06 & 1.73 & 17.9 & 20.0 & 0.19 & 9.46 & 6.5 & 6.6 \\
\hline 15 & 2.13 & 0.30 & 1.72 & - & 0.29 & 0.09 & 6.89 & 25.2 & 14.4 & 1.71 & 10.7 & 6.0 & - \\
\hline 16 & 1.49 & 0.21 & 1.37 & - & 0.20 & 0.07 & 0.98 & 9.81 & 21.1 & 4.61 & 9.71 & 7.0 & - \\
\hline 17 & 2.11 & 0.30 & 1.71 & - & 0.41 & 0.12 & 2.08 & 3.77 & 10.3 & 27.4 & 11.6 & 4.1 & - \\
\hline
\end{tabular}

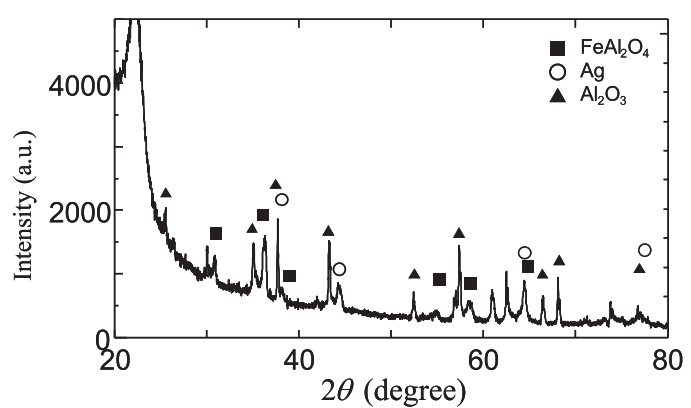

Fig. 8. Powder X-ray diffraction spectrum of the oxides formed in Run 9.

ibration. For Runs 1-7, the relationship between $p_{\mathrm{O}_{2}}$ and the $\mathrm{Cu}$ content of the $\mathrm{Ag}$ and flux phases is shown in Fig. 5. The relationship between $p_{\mathrm{O}_{2}}$ and $L_{\mathrm{Cu} \text { (flux-Ag) }}$ is shown in Fig. 6. $p_{\mathrm{O}_{2}}$ affects the $\mathrm{Cu}$ content of the $\mathrm{Ag}$ and the greatest value of $L_{\mathrm{Cu} \text { (flux-Ag) }}$ is 17 at a partial oxygen pressure of 0.6 atm under the experimental conditions used in this work. The relationship between $p_{\mathrm{O}_{2}}$ and the Ag content of the flux is shown in Fig. 7. The $\mathrm{Ag}$ content of the flux rises with increase in $p_{\mathrm{O}_{2}}$.

\subsection{Oxidative Removal of $\mathrm{Cu}$ from Carbon-saturated Iron via Ag into $\mathrm{B}_{\mathbf{2}} \mathrm{O}_{\mathbf{3}}$ Flux}

The experimental results are shown in Table 5. The $\mathrm{Cu}$ content of the $\mathrm{Ag}$ and $\mathrm{Fe}-\mathrm{C}$ (satd.) before oxidation is calculated from the initial mass of $\mathrm{Fe}, \mathrm{Ag}$ and $\mathrm{Cu}$ and $L_{\mathrm{Cu}(\mathrm{Ag}-\mathrm{Fe})}$ $(=7.15) .{ }^{9)}$ In Runs 9 and 11 , the $\mathrm{Cu}$ content of the $\mathrm{Fe}-$ $\mathrm{C}$ (satd.) and Ag are slightly lower than those before oxidation. In Run 10, the molten iron moves outside of the alumina tube and iron oxide is formed. In the experiments performed with $\mathrm{B}_{2} \mathrm{O}_{3}\left(-\mathrm{Al}_{2} \mathrm{O}_{3}-\mathrm{Ag}_{2} \mathrm{O}\right)$ flux (Runs 12-17), the experimental results are classified into three types: (1) Both the $\mathrm{Cu}$ and $\mathrm{Ag}$ contents of the flux are low and the $\mathrm{Cu}$ content of the $\mathrm{Fe}-\mathrm{C}$ (satd.) and $\mathrm{Ag}$ phases do not decrease (Runs 12 and 13), (2) The $\mathrm{Cu}$ is dissolved into the $\mathrm{B}_{2} \mathrm{O}_{3}$ flux and the $\mathrm{Fe}$ is not dissolved (Runs 14 and 15), (3) Both the $\mathrm{Cu}$ and $\mathrm{Fe}$ are dissolved into the $\mathrm{B}_{2} \mathrm{O}_{3}$ flux (Runs 16 and 17). For Runs 15-17, the $\mathrm{Cu}$ content of the Ag inside the alumina tube cannot be measured because there is an inadequate amount of the Ag phase present. From the result of Run 14, it has been clarified that the $\mathrm{Cu}$ content of the $\mathrm{Fe}-\mathrm{C}$ (satd.) can be decreased to below 0.2 mass $\%$ with the $\mathrm{B}_{2} \mathrm{O}_{3}-\mathrm{Al}_{2} \mathrm{O}_{3}-$ $\mathrm{Ag}_{2} \mathrm{O}$ flux.

In Run 9, the $\mathrm{Cu}$ content of the $\mathrm{Ag}$ inside and outside the alumina tube differs, and the distribution ratio of the $\mathrm{Cu}$ between the $\mathrm{Ag}$ inside the alumina tube and the Fe phases,

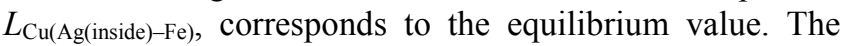
powder X-ray diffraction spectrum of the oxides formed at the path in Run 9 is shown in Fig. 8. $\mathrm{FeAl}_{2} \mathrm{O}_{4}$ is identified and it separates from the $\mathrm{Ag}$ phase at the path.

\section{Discussion}

\subsection{Activity Coefficients of $\mathrm{Cu}_{2} \mathrm{O}$ and $\mathrm{Ag}_{2} \mathrm{O}$ in the $\mathrm{B}_{2} \mathrm{O}_{3}$ Flux}

The activity coefficient of the $\mathrm{Cu}_{2} \mathrm{O}$ in the flux, $\gamma_{\mathrm{Cu}_{2} \mathrm{O} \text { (in flux), }}$ is shown in Eq. (7) based on the equilibrium of Eq. (6).

$$
\begin{array}{r}
2 \mathrm{Cu}(\mathrm{l})+1 / 2 \mathrm{O}_{2}(\mathrm{~g})=\mathrm{Cu}_{2} \mathrm{O}(\mathrm{l}) \ldots \ldots . . \\
\gamma_{\left.\mathrm{Cu}_{2} \mathrm{O} \text { (in flux }\right)}=\frac{\gamma_{\mathrm{Cu}(\text { in Ag) }}^{2} N_{\mathrm{Cu} \text { (in Ag) }}^{2} p_{\mathrm{O}_{2}}^{1 / 2} K_{(6)}}{N_{\left.\mathrm{Cu}_{2} \mathrm{O} \text { (in flux }\right)}}
\end{array}
$$

The value of the $\gamma_{\mathrm{Cu}_{2} \mathrm{O} \text { (in flux) }}$ is calculated by substituting $K_{(6)}(=102.3),{ }^{11)} \gamma_{\mathrm{Cu}(\mathrm{in} \mathrm{Ag})}^{\circ}(=3.14)^{14)}$ and the experimental conditions and results into Eq. (7). The relationship between $N_{\mathrm{B}_{2} \mathrm{O}_{3} \text { (influx) }}$ and $\gamma_{\mathrm{Cu}_{2} \mathrm{O} \text { (in flux) }}$ is shown in Fig. 9. $\gamma_{\mathrm{Cu}_{2} \mathrm{O} \text { (in flux) }}$

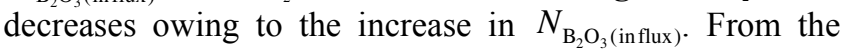
results, the $\mathrm{B}_{2} \mathrm{O}_{3}$ flux has an affinity for $\mathrm{Cu}_{2} \mathrm{O}$ and it is possible to remove the $\mathrm{Cu}$ into the $\mathrm{B}_{2} \mathrm{O}_{3}$ flux.

The distribution ratio of $\mathrm{Cu}$ between the flux and molten

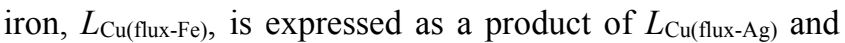
$L_{\mathrm{Cu}(\mathrm{Ag}-\mathrm{Fe})}$. The value of $L_{\mathrm{Cu}(\mathrm{Ag}-\mathrm{Fe})}$ measured in previous work is $7.15^{9)}$ in the region of the dilute solution. From this work, the largest value of $L_{\mathrm{Cu}(f l u x-\mathrm{Ag})}$ is 17 at a partial oxygen pressure of $0.6 \mathrm{~atm}$ under these experimental conditions and $L_{\mathrm{Cu}(\mathrm{flux}-\mathrm{Fe})}$ is estimated to be up to approximately 120 .

On the other hand, the oxidation of Ag is expressed as follows. ${ }^{11)}$

$$
\begin{gathered}
2 \mathrm{Ag}(\mathrm{l})+1 / 2 \mathrm{O}_{2}(\mathrm{~g})=\mathrm{Ag}_{2} \mathrm{O}(\mathrm{s}) \\
\Delta G_{(8)}^{\circ}=-53100+84.1 T(\mathrm{~J} / \mathrm{mol})
\end{gathered}
$$

Because pure $\mathrm{Ag}_{2} \mathrm{O}$ is decomposed entirely at $1523 \mathrm{~K}$, the standard of activity is selected as solid $\mathrm{Ag}_{2} \mathrm{O}$ as was used 


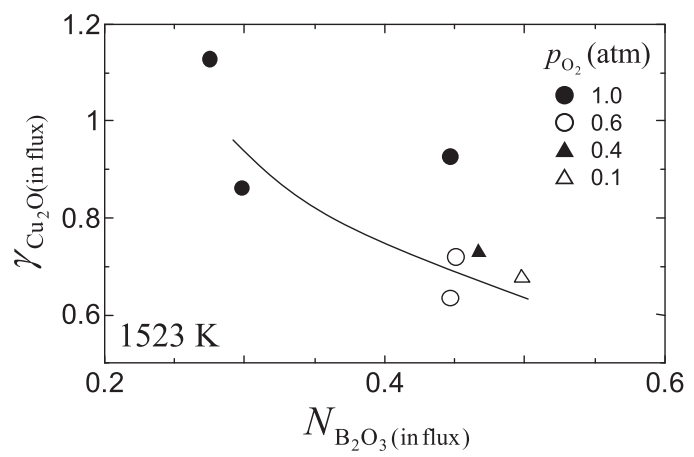

Fig. 9. Relationship between $N_{\mathrm{B}_{2} \mathrm{O}_{3} \text { (influx) }}$ and $\gamma_{\mathrm{Cu}_{2} \mathrm{O} \text { (in flux) }}$ at $1523 \mathrm{~K}$.

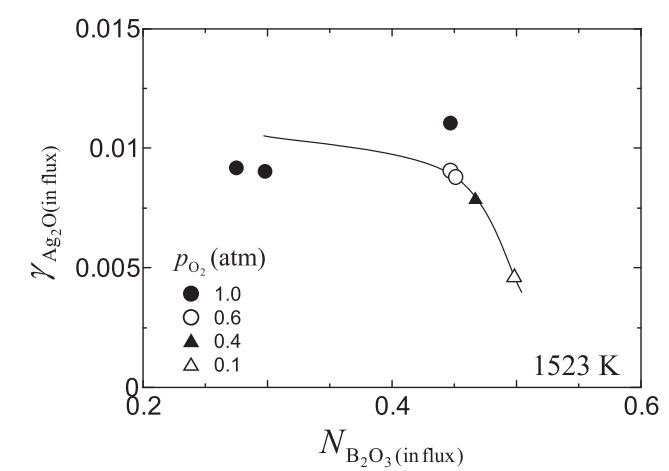

Fig. 10. Relationship between $N_{\mathrm{B}_{2} \mathrm{O}_{3} \text { (influx) }}$ and $\gamma_{\mathrm{Ag}_{2} \mathrm{O} \text { (in flux) }}$ at $1523 \mathrm{~K}$.

by Wakasugi et al. ${ }^{15)} a_{\mathrm{Ag}_{2} \mathrm{O}}$ is determined by the $p_{\mathrm{O}_{2}}$ because $a_{\mathrm{Ag}}$ is assumed to be nearly unity. Fig. 10 shows $\gamma_{\mathrm{Ag}_{2} \mathrm{O} \text { (in flux) }}$ as a function of $N_{\mathrm{B}_{2} \mathrm{O}_{3} \text { (in flux) }}$. The value of $\gamma_{\mathrm{Ag}_{2} \mathrm{O} \text { (in flux) }}$ decreases owing to the increase in $N_{\mathrm{B}_{2} \mathrm{O}_{3} \text { (influx) }}$

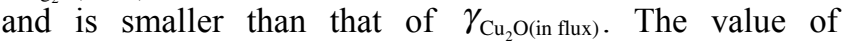
$\gamma_{\mathrm{Cu}_{2} \mathrm{O}(\text { in flux })}$ increases owing to the increase in $p_{\mathrm{O}_{2}}$ because the $\mathrm{B}_{2} \mathrm{O}_{3}$ content of the flux decreases as a result of the increase in $\mathrm{Ag}\left(\mathrm{Ag}_{2} \mathrm{O}\right)$ content at high $p_{\mathrm{O}_{2}}$, as shown in Fig. 7. As a result, there is an optimal $p_{\mathrm{O}_{2}}(0.6 \mathrm{~atm})$ which maximizes the value of $L_{\mathrm{Cu}(\mathrm{flux}-\mathrm{Ag})}$ as shown in Fig. 6.

\subsection{Behavior of Solute Elements in the Oxidative Removal of $\mathrm{Cu}$ with $\mathrm{B}_{2} \mathrm{O}_{3}$ Flux}

In Run 9, the Ag phase is separated at and around the path because the $\mathrm{Fe}$ and $\mathrm{O}$ in the $\mathrm{Ag}$ phase and the alumina react to form $\mathrm{FeAl}_{2} \mathrm{O}_{4}$. In Run 10, the experiment, of which the apparatus is shown in Fig. 3(b), is performed on condition that the path is widened sufficiently. As a result, molten iron is pushed from the inside to the exterior of the alumina tube. This is because the dissolved oxygen reaches the $\mathrm{Fe}-\mathrm{Ag}$ interface, and the inner pressure of the alumina tube rises because of the $\mathrm{CO}$ gas generation. In Run 9, the molten iron is not pushed out of the tube because the transfer of oxygen inside the alumina tube is prevented. In a similar way, the distribution ratio of $\mathrm{Cu}$ between $\mathrm{Fe}-\mathrm{C}$ (satd.) and $\mathrm{Ag}$ inside the alumina tube is equal to the equilibrium value $(=7.15)^{9)}$ because transfer of the $\mathrm{Cu}$ is also prevented. Therefore, control of the oxygen supply is important.

On the other hand, the $\mathrm{B}_{2} \mathrm{O}_{3}$ flux is expected to control the amount of oxygen transported in Runs 12 and 13. However, oxidation of the $\mathrm{Cu}$ in the $\mathrm{Ag}$ phase does not occur because the velocity of the oxygen solution into the flux is low. On the other hand, the $\mathrm{Cu}$ is dissolved into the flux in the experiment using the $\mathrm{B}_{2} \mathrm{O}_{3}-\mathrm{Al}_{2} \mathrm{O}_{3}-\mathrm{Ag}_{2} \mathrm{O}$ flux whose oxygen potential is high (Runs 14-17).

The cross sectional area at the path of Runs 16 and 17 is larger than that of Runs 14 and 15. As a result, the $\mathrm{Cu}$ and $\mathrm{Ag}$ are dissolved into the flux in Runs 14 and 15, and the $\mathrm{Cu}, \mathrm{Fe}$ and $\mathrm{Ag}$ are dissolved into the flux in Runs 16 and 17. From the results, most of the $\mathrm{Cu}$ dissolved in the flux seems to be derived from the $\mathrm{Cu}$ in the $\mathrm{Ag}$ which exists in the initial stage before oxidation. In Runs 16 and 17, the Fe is oxidized via Ag into the flux because of the sufficient cross sectional area at the path. The behavior of the $\mathrm{Fe}, \mathrm{Cu}$ and $\mathrm{O}$ in the $\mathrm{Ag}$ is discussed as described by numerical calculation in Section 5.3.

\subsection{Behavior of Solute Elements as Described by Numerical Calculation}

The diffusion coefficients of $\mathrm{Cu}, \mathrm{Fe}$ and $\mathrm{O}$ in the $\mathrm{Ag}$ at $1523 \mathrm{~K}$ are $4.49 \times 10^{-9}\left(\mathrm{~m}^{2} / \mathrm{s}\right), 4.93 \times 10^{-9}\left(\mathrm{~m}^{2} / \mathrm{s}\right)$ and $1.76 \times 10^{-8}$ $\left(\mathrm{m}^{2} / \mathrm{s}\right)$, respectively. ${ }^{16)}$ The solubility of the oxygen in the $\mathrm{Ag}$ is 0.24 mass \% at a partial oxygen pressure of $1 \mathrm{~atm} .{ }^{17)}$

The one dimensional $\mathrm{Ag}$ phase whose length is $20 \mathrm{~mm}$ is defined for the calculation. The $\mathrm{Fe}-\mathrm{Ag}$ interface and the Agflux interface are located at 0 and $20 \mathrm{~mm}$, respectively. Initially, the behavior of the diffusion of $\mathrm{Cu}, \mathrm{Fe}$ and $\mathrm{O}$ is calculated based on Fick's second law without consideration of the oxidative reaction. The calculation conditions are as follows:

(1) At $0 \mathrm{~mm}$, the mole fractions of $\mathrm{Cu}$ and $\mathrm{Fe}$ in the $\mathrm{Ag}$ are fixed at 0.05 and 0.0012 (3.0 mass $\%$ and 0.06 mass $\%$ ), respectively.

(2) At $0 \mathrm{~mm}$, the mole fraction of $\mathrm{O}$ is fixed to be zero because the oxygen that reaches the $\mathrm{Fe}-\mathrm{Ag}$ interface and carbon contained in the $\mathrm{Fe}-\mathrm{C}$ (satd.) react and $\mathrm{CO}$ gas is generated.

(3) At $20 \mathrm{~mm}$, the mole fraction of $\mathrm{Cu}$ is fixed to be $0.0252(1.5 \mathrm{mass} \%)$. This value is determined from previous work performed without oxide flux at a partial oxygen pressure of $1 \mathrm{~atm} .{ }^{9)}$ The mole fraction of the Fe is fixed to be zero because the transported Fe is fully oxidized.

(4) At $20 \mathrm{~mm}$, the mole fraction of $\mathrm{O}$ is fixed to be 0.016 $(0.24$ mass $\%)$, which is the solubility of the oxygen in the $\mathrm{Ag}$ at a partial oxygen pressure of $1 \mathrm{~atm}$.

The mole fractions of $\mathrm{Cu}, \mathrm{Fe}$ and $\mathrm{O}$ are calculated based on these conditions and their steady states are shown in Fig. 11. Contents are expressed as mole fraction, $N_{i}(i=\mathrm{Cu}, \mathrm{Fe}$, $\mathrm{O}$ ). The absolute quantity of $\mathrm{Cu}$ is larger than that of $\mathrm{Fe}$. Therefore, the calculation is performed in consideration of the oxidative reaction of $\mathrm{Cu}$ and out of consideration of that of Fe. The calculation conditions are as follows:

(1) Under the initial condition, the mole fraction of $\mathrm{Cu}$ over the whole position is 0.05 .

(2) The mole fraction of $\mathrm{Cu}$ at $0 \mathrm{~mm}$ is fixed at 0.05 .

(3) Under the initial conditions, the mole fractions of $\mathrm{O}$ at $20 \mathrm{~mm}$ and the other position are 0.016 and 0 , respectively.

(4) $\mathrm{The} \mathrm{Cu}$ and $\mathrm{O}$ react immediately and the $\mathrm{Cu}_{2} \mathrm{O}$ formed is removed from the system.

(5) The lowering limit of $\mathrm{Cu}$ is 0.0252 , which is the equilibrium value at a partial oxygen pressure of $1 \mathrm{~atm}$.

Calculation result of the $\mathrm{Cu}$ and $\mathrm{O}$ mole fractions is shown in Fig. 12. The $\mathrm{Cu}$ content of the Ag decreases with time and reaches steady state in approximately $11 \mathrm{ks}$. The 


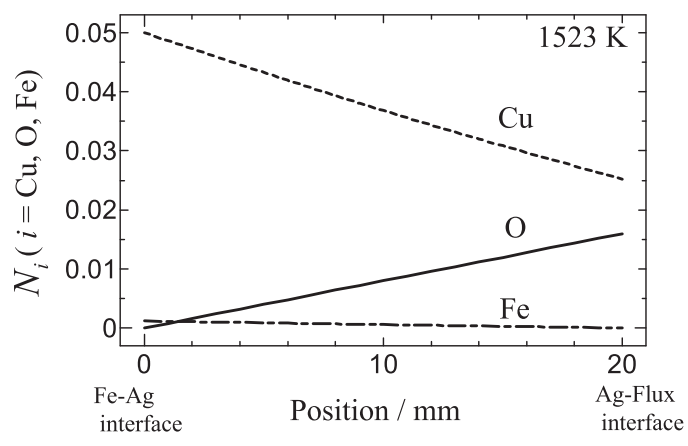

Fig. 11. Diffusion of $\mathrm{Cu}, \mathrm{O}$ and $\mathrm{Fe}$ disregarding the oxidative reaction.

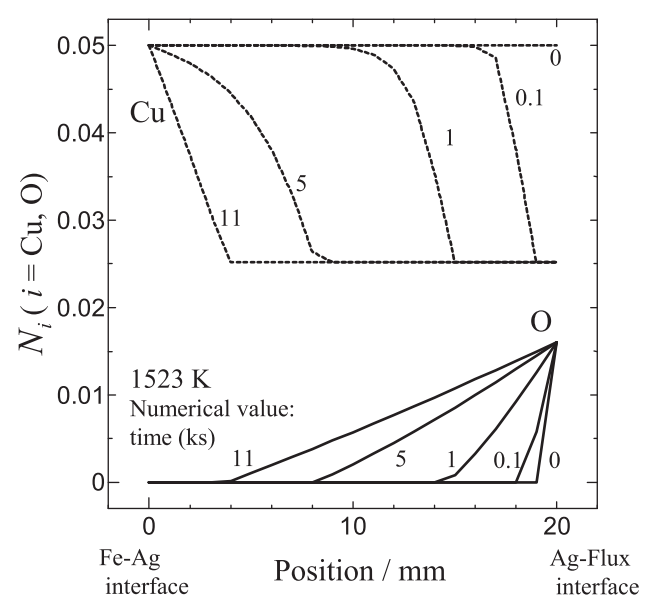

Fig. 12. Diffusion of $\mathrm{Cu}$ and $\mathrm{O}$ including the oxidative reaction owing to diffusion time at $1523 \mathrm{~K}$.

oxidative reaction occurs at a fixed position $(4 \mathrm{~mm})$, on condition that a stable supply of $\mathrm{Cu}$ and oxygen gas is provided and the length of the $\mathrm{Ag}$ phase is $20 \mathrm{~mm}$. In a similar way, the $\mathrm{O}$ content increases with time, and the reaction achieves steady state for $11 \mathrm{ks}$. These results show that fixing the position of the oxidative reaction outside the alumina tube makes it possible to promote the oxidative reaction of $\mathrm{Cu}$ without reaching the oxygen at the $\mathrm{Fe}-\mathrm{Ag}$ interface. The calculation results at steady state are shown in Fig. 13 where the initial mole fractions of $\mathrm{Cu}$ at the $\mathrm{Fe}-\mathrm{Ag}$ interface are fixed to be $0.1,0.05$ and 0.04 . The initial mole fraction of $\mathrm{Cu}$ in the $\mathrm{Fe}-\mathrm{Ag}$ interface decreases, the position of the oxidative reaction gradually moves to the negative direction. When the $\mathrm{Cu}$ content of the $\mathrm{Fe}-\mathrm{C}$ (satd.) becomes low, the $\mathrm{Cu}$ content of the $\mathrm{Fe}-\mathrm{Ag}$ interface also becomes low and the oxygen gets close to the $\mathrm{Fe}-\mathrm{Ag}$ interface. When the $\mathrm{Cu}$ content of the $\mathrm{Fe}-\mathrm{C}$ (satd.) and $\mathrm{Ag}$ phases reaches equilibrium, transportation of the $\mathrm{Cu}$ appears to cease. As a result, oxygen dissolved in the $\mathrm{Ag}$ reaches the $\mathrm{Fe}-\mathrm{Ag}$ interface and $\mathrm{CO}$ gas appears to be generated. In fact, oxygen reaches the $\mathrm{Fe}-$ $\mathrm{Ag}$ interface and $\mathrm{CO}$ gas is generated before the $\mathrm{Cu}$ content reaches equilibrium in Runs 15-17. Because of the generation of the $\mathrm{CO}$ gas, part of the $\mathrm{Ag}$ inside the alumina tube appears to be pushed out of the alumina tube in Run 15, and part of the Fe and most of the $\mathrm{Ag}$ inside the alumina tube are pushed out in Runs 16 and 17. Besides, once the oxygen reaches inside the alumina tube, the formed $\mathrm{Fe}$ and $\mathrm{Cu}$ oxides appear to reach the $\mathrm{Fe}-\mathrm{Ag}$ interface and are reduced by carbon. Therefore, only the decarburization reaction

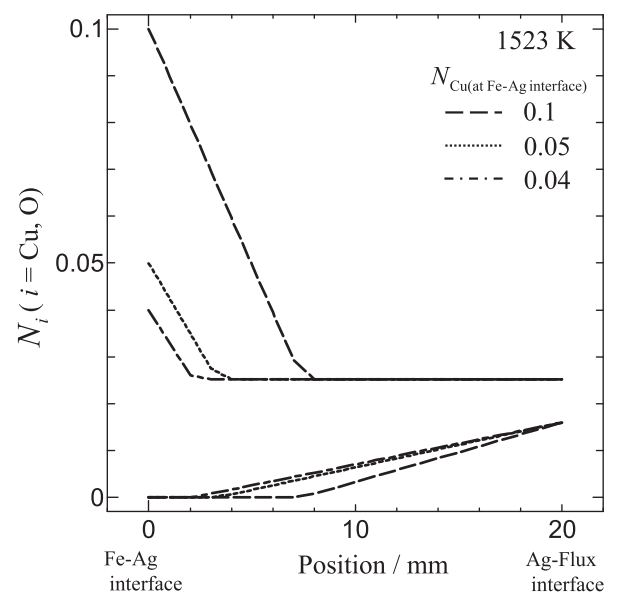

Fig. 13. Relationship between $\mathrm{Cu}$ and $\mathrm{O}$ contents in the $\mathrm{Ag}$ phase owing to initial $\mathrm{Cu}$ content.

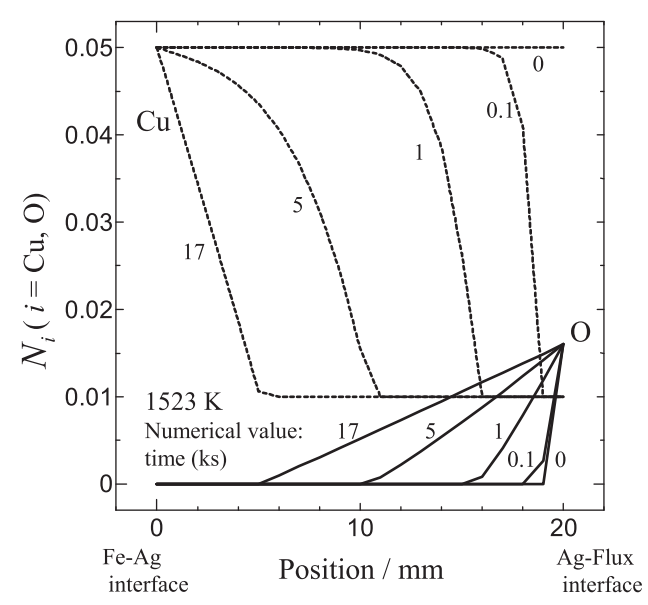

Fig. 14. Oxidation of $\mathrm{Cu}$ where the lower limit of $\mathrm{Cu}$ is decreased by oxide flux at $1523 \mathrm{~K}$.

appears to occur. Under the experimental conditions of this work, oxygen will easily reach the inside of the alumina tube because the $\mathrm{Cu}$ content of the $\mathrm{Fe}-\mathrm{C}$ (satd.) before oxidative removal is close to the lower limit $(0.26$ mass $\%)$ and the amount of $\mathrm{Cu}$ which moves from the $\mathrm{Fe}-\mathrm{C}$ (satd.) to the $\mathrm{Ag}$ phases is low. Based on this discussion, it is possible to increase the driving force of the distribution of $\mathrm{Cu}$ by decreasing the value of $a_{\mathrm{Cu}_{2} \mathrm{O}}$ with the oxide flux. The calculation result is shown in Fig. 14 when the lower limit of $\mathrm{Cu}$ in the $\mathrm{Ag}$ decreases to 0.01 (0.6 mass\%) using the oxide flux. The value of $a_{\mathrm{Cu}_{2} \mathrm{O}}$ is calculated to be 0.10 under this condition. Other calculating conditions are the same as the calculation in Fig. 12(b). As a result, the time to achieve steady state is $17 \mathrm{ks}$ and the reaction position is $5 \mathrm{~mm}$. By comparison of Fig. 14 with Fig. 12(b), the reaction position moves towards the Ag-flux interface by $1 \mathrm{~mm}$ and the time to reach steady state becomes long because the amount of reactive $\mathrm{Cu}$ increases. From the comparison, using the oxide flux for $\mathrm{Cu}$ removal seems to be effective in inhibiting the movement of oxygen into the alumina tube.

Based on this discussion, the methods for promoting effective $\mathrm{Cu}$ removal appear to be as follows:

(1) To decrease the lower limit of $\mathrm{Cu}$ with the oxide flux to allow for the oxidative reaction to occur outside the alumina tube, 
(2) To move the reaction position of $\mathrm{Cu}$ and $\mathrm{O}$ close to the Ag-flux interface by stirring the Ag phase between the $\mathrm{Fe}-\mathrm{Ag}$ interface and the reaction position or by stopping the oxygen supply temporarily for the enhancement of the distribution of $\mathrm{Cu}$.

\section{Conclusion}

Measurement of the activity coefficient of $\mathrm{Cu}_{2} \mathrm{O}$ in the $\mathrm{B}_{2} \mathrm{O}_{3}$ flux and the oxidative removal of $\mathrm{Cu}$ from the $\mathrm{Fe}-$ $\mathrm{C}$ (satd.) via $\mathrm{Ag}$ into the $\mathrm{B}_{2} \mathrm{O}_{3}$ flux were performed at $1523 \mathrm{~K}$ for the removal of $\mathrm{Cu}$ dissolved in molten iron. The conclusions are as follows:

(1) The $\mathrm{B}_{2} \mathrm{O}_{3}$ flux has a large capacity for $\mathrm{Cu}$ because it decreases $\gamma_{\mathrm{Cu}_{2} \mathrm{O}(\text { in flux) }}$. Not only $\mathrm{Cu}$ but also $\mathrm{Ag}$ is dissolved in the flux as an oxide and this provides the most suitable partial oxygen pressure for the treatment. Under this experimental condition, the largest value of $L_{\mathrm{Cu}(\mathrm{flux}-\mathrm{Ag})}$ is 17 at an oxygen partial pressure of 0.6 atm. The value of $L_{\mathrm{Cu} \text { (flux-Fe) }}$ is estimated to be approximately 120 from the value of $L_{\mathrm{Cu} \text { (flux-Ag) }}$ and $L_{\mathrm{Cu}(\mathrm{Fe}-\mathrm{Ag}) \text {. }}$

(2) From the oxidative removal of $\mathrm{Cu}$ from the $\mathrm{Fe}-$ $\mathrm{C}$ (satd.) via $\mathrm{Ag}$ into the $\mathrm{B}_{2} \mathrm{O}_{3}$ flux, the $\mathrm{Cu}$ in the metal is dissolved into the flux by using the $\mathrm{B}_{2} \mathrm{O}_{3}-\mathrm{Al}_{2} \mathrm{O}_{3}-\mathrm{Ag}_{2} \mathrm{O}$ flux.

(3) From the numerical calculation, controlling the rate of oxygen supply, stirring the Ag phase inside the alumina tube and decreasing the lower limit of $\mathrm{Cu}$ with the oxide flux are required for the continuous oxidative removal of $\mathrm{Cu}$.

\section{Acknowledgment}

We would like to thank the Iron and Steel Institute "ISIJ Research Promotion Grant" and Osaka University G-COE program "Center of Excellence for Advanced Structural and Functional Materials Design" for the financial support of this work.

\section{REFERENCES}

1) The Japan Ferrous Raw Materials Association: annual report of iron source, The Japan Ferrous Raw Materials Association, Tokyo, (2011), 30.

2) M. Iwase and K. Tokinori: Steel Res., 62 (1992), 235.

3) M. Iwase, K. Tokinori and H. Ohshita: ISS Trans., (1993), 61.

4) M. Iwase and H. Ohshita: Steel Res., 65 (1994), 362.

5) K. Zhou, K. Shinme and S. Anezaki: J. MMIJ, 111 (1995), 49.

6) K. Yamaguchi and Y. Takeda: Metall. Rev. MMIJ, 113 (1997), 1110.

7) K. Marukawa, T. Tanaka and S. Hara: Eng. Mater., 48 (2000), 62.

8) K. Taguchi, H. Ono-Nakazato and T. Usui: ISIJ Int., 46 (2006), 29.

9) K. Yamaguchi, H. Ono and T. Usui: Tetsu-to-Hagané, 96 (2010), 531

10) H. Ono, Y. Tanaka, K. Yamaguchi and T. Usui: Tetsu-to-Hagané, 96 (2010), 641 .

11) E. T. Turkdogan: Physical Chemistry of High Temperature Technology, Academic Press, New York, (1980), 5, 10.

12) K. Morinaga, H. Yoshida and H. Takebe: J. Am. Ceram. Soc., 77 (1994), 3113.

13) P. J. M. Gielisse and W. R. Foster: Nature, 195 (1962), 69

14) R. Hultgren, P. Desai, D. Hawkins, M. Gleiser and K. K. Kelley: Selected Values of the Thermodynamic Properties of Binary Alloys, American Society for Metals, Metal Park, Ohio (1968), 44.

15) T. Wakasugi, A. Hirota, J. Fukunaga and R. Ota: J. Non-Cryst. Solids, 210 (1997), 141.

16) The 140th Committee of Japan Society for Promotion of Science: Handbook of Physico-chemical Properties at High Temperatures, ed. by Y. Kawai and Y. Shiraishi, ISIJ, Tokyo, (1988), 184, 185.

17) I. D. Shah and N. A. D. Parlee: Trans. Metall. Soc. AIME, 239 (1967), 763. 